\title{
Higiene dan Sanitasi pada Pedagang Angkringan di Kawasan Malioboro Yogyakarta
}

\author{
${ }^{1}$ Dyah Suryani, ${ }^{2}$ Fardhiasih Dwi Astuti \\ ${ }^{1,2}$ Program Studi Kesehatan Masyarakat, FKM, Universitas Ahmad Dahlan, Yogyakarta \\ Jalan Prof. Dr. Soepomo, SH, Janturan, Warungboto, Yogyakarta 55154 \\ dyahsuryani.ds@gmail.com
}

\begin{abstract}
ABSTRAK
Penyakit bawaan makanan banyak disebabkan oleh buruknya teknik penanganan makanan, dan terjadi kontaminasi pada saat disajikan. Higiene penjamah makanan dan sanitasi merupakan kunci keberhasilan dalam pengolahan makanan yang aman dan sehat. Keadaan higiene dan sanitasi yang buruk dapat mempengaruhi kualitas makanan. Hal ini berpengaruh terhadap tingkat kesehatan konsumen yang mengkonsumsi makanan tersebut. Jika higiene sanitasi makanannya buruk maka dapat mengakibatkan timbulnya masalah-masalah kesehatan. Tujuan dalam penelitian ini untuk mengetahui faktor-faktor yang berhubungan dengan higiene sanitasi pada pedagang angkringan di kawasan Malioboro. Jenis penelitian ini adalah observasional analitik dengan desain cross sectional. Sampel penelitian yaitu pedagang angkringan di Kawasan Malioboro dengan jumlah 40 pedagang angkringan. Teknik pengambilan sampel dengan total sampling. Instrumen yang digunakan adalah kuesioner dan lembar checklist. Analisis data yang digunakan analisis univariat dan analisis bivariat dengan uji statistik Fisher. Hasil uji statistik penelitian kepada 40 pedagang angkringan, menunjukkan bahwa sebanyak 32 pedagang mempunyai pengetahuan tinggi $(80 \%), 36$ pedagang mempunyai sikap baik (90\%), 29 pedangang mempunyai fasilitas sanitasi buruk $(72.5 \%), 26$ pedagang mempunyai higiene yang buruk $(65 \%)$. Tidak ada hubungan antara pengetahuan $(\mathrm{p}=0.222)$, sikap $(\mathrm{p}=1.000)$ dengan higiene pedagang. Ada hubungan antara fasilitas sanitasi dengan higiene pedagang $(\mathrm{p}=0.029)$.
\end{abstract}

Kata kunci : Pengetahuan, Sikap, Fasilitas Sanitasi, Higiene, Sanitasi.

\begin{abstract}
Foodborne disease more of the cases caused by poor food handling techniques, and contamination occurs when served. Food handler hygiene and sanitation are the key to be success in processing safe and healthy foods. Poor sanitation hygiene can be affect the quality of the food. It cause consumer health level who is consume these food. If the hygiene and sanitation of food bad it could result in health problems. Based on this background, the study are interested in knowing the factors related to sanitation hygiene in angkringan traders in the Malioboro area. This study was observasional analitic with cross sectional design. The study sample was angkringan traders in Malioboro area with 40 angkringan traders. Sampling technique with total sampling. The instruments used questionnaire and checklist sheets. Data analysis used univariate analysis and bivariate analysis with Fisher statistical test. The results of the study statistics test for 40 angkringan traders, showed that 32 traders had high knowledge (80\%), 36 traders had a good attitude (90\%), 29 traders had poor sanitation facilities (72.5\%), 26 traders had bad hygiene $(65 \%)$. There is no relationship between knowledge $(\mathrm{p}=0.222)$, attitude $(\mathrm{p}=1.000)$ with hygiene of traders. There is a relationship between sanitation facilities and hygiene traders $(\mathrm{p}=0.029)$.
\end{abstract}

Keywords: Knowledge, attitude, sanitation facilities, hygiene, sanitation. 


\section{Pendahuluan}

Makanan adalah salah satu kebutuhan pokok manusia untuk dapat melangsungkan kehidupannya. Selain mengandung nilai gizi, makanan juga merupakan media bagi mikroba atau kuman untuk berkembang biak. Kemungkinan lain masuknya bahan-bahan berbahaya seperti bahan kimia, residu pestisida serta bahan lainnya seperti debu, tanah, rambut manusia dapat berpengaruh buruk terhadap kesehatan manusia ${ }^{1}$.

Makanan merupakan kebutuhan mendasar bagi hidup manusia, akan tetapi makanan juga sangat mungkin menjadi penyebab terjadinya gangguan dalam tubuh. Salah satu cara untuk memelihara kesehatan adalah dengan mengkonsumsi makanan yang aman, yaitu memastikan bahwa makanan tersebut tidak kontaminasi. Kontaminasi dapat menyebabkan makanan tersebut menjadi media bagi suatu penyakit. Penyakit yang ditimbulkan oleh makanan yang terkontaminasi disebut penyakit bawaan makanan (food-borned disease $)^{2}$.

WHO memperkirakan 1 dari 10 orang terkena penyakit bawaan makanan dan sebagai akibatnya 420.000 orang meninggal setiap tahun. Afrika dan Asia Tenggara merupakan wilayah dengan insiden dan tingkat kematian tertinggi ${ }^{3}$. Statistik penyakit bawaan makanan yang ada di berbagai negara industri saat ini menunjukkan bahwa 60\% dari kasus yang ada disebabkan oleh buruknya teknik penanganan makanan, dan terjadi kontaminasi pada saat disajikan di Tempat Pengelolaan Makanan (TPM). Kebersihan penjamah makanan atau higienis penjamah makanan dan sanitasi merupakan kunci keberhasilan dalam pengolahan makanan yang aman dan sehat ${ }^{4}$. Hygiene penjamah adalah usaha penjamah makanan dalam menjaga kebersihan tangan, pakaian kerja, kebersihan rambut, dan kesehatan diri ${ }^{5}$. Sanitasi adalah usaha kesehatan preventif yang menitikberatkan kegiatan kepada usaha kesehatan lingkungan hidup manusia ${ }^{6}$.

Higiene pada pedagang sangat berpengaruh terhadap keamanan pangan, agar bahan pangan tidak tercemar. Sedangkan sanitasi tempat penjualan dilakukan untuk pengendalian kondisi lingkungan sejak penanganan bahan baku sampai proses distribusi. Peran sanitasi menjadi sangat penting sebagai upaya untuk mencegah kemungkinan tumbuh dan berkembangnya mikroba pembusuk dan patogen dalam makanan, minuman, peralatan, dan bangunan yang dapat merusak pangan dan membahayakan manusia ${ }^{7}$.

Keadaan higiene sanitasi yang buruk dapat mempengaruhi kualitas makanan yang disajikan kepada konsumen. Hal ini jelas akan berpengaruh juga terhadap tingkat kesehatan konsumen yang mengkonsumsi makanan tersebut. Jika higiene sanitasi makanannya buruk maka dapat mengakibatkan timbulnya masalah-masalah kesehatan ${ }^{2}$.

Di Indonesia penyakit karena makanan masih menjadi masalah kesehatan masyarakat karena masih sering dilaporkan kejadian keracunan makanan di banyak daerah. Pada bulan Januari hingga Maret 2016, terdapat insiden keracunan akibat pangan sebanyak 31 insiden (30 makanan, 1 minuman). Keracunan akibat pangan berturut-turut disebabkan oleh 
Dyah Suryani dan Fardhiasih Dwi Astuti. Higiene dan Sanitasi Pada Pedagang Angkringan Di Kawasan Malioboro Yogyakarta

DOI :

pangan olahan rumah tangga sebanyak 12 insiden keracunan dengan jumlah korban 792 orang, pangan jasaboga sebanyak 9 insiden keracunan dengan jumlah korban 354 orang dengan 2 korban diantaranya meninggal, pangan keracunan dengan jumlah korban 190 orang dengan 1 korban meninggal, pangan olahan dalam kemasan sebanyak 3 insiden keracunan dengan korban 120 orang, dan 1 insiden keracunan akibat minuman keras oplosan dengan jumlah korban 42 orang dengan 24 korban meninggal ${ }^{8}$.

Kasus keracunan makanan merupakan masalah kesehatan bagi masyarakat Yogyakarta yang dianggap sebagai fenomena suatu kejadian yang luar biasa (KLB). KLB keracunan makanan di Yogyakarta tahun 2014 tercatat sejumlah 734 orang dari 5 kabupaten ${ }^{9}$.

Angkringan adalah salah satu bentuk warung makan yang ada di Yogyakarta, angkringan biasanya bertempat di pinggir jalan atau di atas trotoar. Makanan yang dijual di angkringan sangat bervariasi dan terjangkau harganya seperti nasi kucing, aneka gorengan, sate, atau berbagai hidangan lainnya beserta $\operatorname{minuman}^{10}$.

Berdasarkan survey pada pedagang angkringan di Kawasan Malioboro, masih ditemukan pedagang yang tidak melakukan cuci tangan baik sebelum maupun setelah melayani pembeli, pedagang dalam melayani pembeli masih merokok, pedagang langsung menggunakan tangan saat mengambil es batu tanpa menggunakan peralatan, tempat sampah yang ada di angkringan tidak diberi tutup, air yang digunakan pedagang dalam mencuci peralatan hanya menggunakan 2 ember air dan makanan seperti gorengan maupun sate-satean yang berada di angkringan ini tidak ada penutupnya. Karena kondisi pedagang dalam menyajikan makanan masih kurang baik, maka dengan kondisi tersebut dapat berisiko dengan penularan berbagai macam penyakit. Para pedagang juga masih memiliki pengetahuan yang kurang mengenai higiene sanitasi. Tujuan dalam penelitian ini adalah untuk mengetahui faktor-faktor yang berhubungan dengan higiene sanitasi pada pedagang angkringan di kawasan Malioboro.

\section{Metode}

Jenis penelitian ini merupakan penelitian observasional analitik dengan desain penelitian cross-sectional. Penelitian ini dilakukan di kawasan Malioboro Yogyakarta. Sampel pada penelitian ini yaitu pedagang angkringan di kawasan Malioboro Yogyakarta. Penelitian ini menggunakan teknik totality sampling dengan cara mengambil seluruh populasi yang ada dengan jumlah responden sebanyak 40 pedagang angkringan. Instrumen yang digunakan dalam penelitian ini adalah lembar kuesioner untuk mengukur tingkat pengetahuan dan sikap dan lembar observasi untuk menilai fasilitas sanitasi dan higiene pedagang. Pengambilan penelitian dilakukan dengan observasi langsung ke tempat pedagang angkringan di wilayah Malioboro. Kuesioner pengetahuan higiene sanitasi pada pedagang terdiri dari 13 item pertanyaan, sedangkan kuesioner sikap higiene sanitasi pada pedagang terdiri dari 11 item pertanyaan menggunakan skala pengukuran skala Guttman. Lembar observasi fasilitas sanitasi terdiri dari 
ketersediaan air bersih, ketersediaan tempat sampah, ketersediaan serbet, ketersediaan tempat penyimpanan peralatan. Lembar observasi yang digunakan dalam pengukuran higiene pedagang angkringan terdiri dari 23 praktik higiene dengan skala pengukuran menggunakan skala Guttman. Hasil dari pengisian kuesioner pengetahuan dan sikap serta lembar observasi fasilitas sanitasi dan higiene pedagang kemudian dikonversikan ke dalam persentase. Dikatakan buruk apabila skor jawaban dibawah $70 \%$ dan dikatakan baik apabila skor jawaban lebih atau sama dengan 70\%. Analisis data dilakukan dengan uji univariat untuk mengetahui distribusi frekuensi dan karena syarat chi-square tidak terpenuhi maka menggunakan uji alternative fisher exact test untuk mengetahui hubungan variabel independen dengan variabel dependen (CI $95 \%)(\mathrm{p}=0.05)$.

\section{Hasil}

Tabel 1. Distribusi Frekuensi Karakteristik Pedagang Angkringan di Kawasan Malioboro

\begin{tabular}{lcc}
\hline Karakteristik & N & \% \\
\hline Umur & & \\
Lansia & 23 & 57.5 \\
Dewasa & 17 & 42.5 \\
Pendidikan & & \\
Rendah & 21 & 52.5 \\
Tinggi & 19 & 47.5 \\
Lama Berjualan & & \\
>5 Tahun & 36 & 90 \\
< Tahun & 4 & 10 \\
Pelatihan & & \\
Belum Pernah & 37 & 92.5 \\
\hline Pernah & 3 & 7.5 \\
\hline
\end{tabular}

Berdasarkan tabel 1 terlihat bahwa mayoritas responden berjenis kelamin laki-laki yang berjumlah 35 orang $(87.5 \%)$, responden dengan kelompok umur lansia berjumlah 23 orang $(57.5 \%)$, responden memiliki pendidikan rendah berjumlah 21 orang $(52.5 \%)$ dan mayoritas responden mempunyai lama berjualan $>5$ tahun yang berjumlah 36 orang (90\%).

Tabel 2. Distribusi Frekuensi Pengetahuan, Sikap, Fasilitas Sanitasi dan Higiene Sanitasi Pedagang Angkringan di Kawasan Malioboro

\begin{tabular}{lcc}
\hline Variabel & n & \% \\
\hline Pengetahuan & & \\
Rendah & 8 & 20 \\
Tinggi & 32 & 80 \\
\hline Sikap & & \\
Buruk & 4 & 10 \\
Baik & 36 & 90 \\
\hline Fasilitas Sanitasi & & \\
Buruk & 29 & 72.5 \\
Baik & 11 & 27.5 \\
\hline Higiene Pedagang & & \\
Buruk & 26 & 65 \\
Baik & 14 & 35 \\
\hline
\end{tabular}

Tingkat pengetahuan tentang higiene sanitasi pada pedagang angkringan mayoritas mempunyai pengetahuan tentang higiene sanitasi yang tinggi yaitu sebanyak sebanyak 32 responden $(80 \%)$. Pedagang angkringan telah mempunyai sikap tentang higiene sanitasi yang baik sebanyak 36 responden (90\%). Sedangkan fasilitas sanitasi pada pedagang angkringan mempunyai kriteria buruk berjumlah 29 responden $(72.5 \%)$ dan higiene pada pedagang angkringan yang buruk berjumlah 26 responden $(65 \%)$. 
Dyah Suryani dan Fardhiasih Dwi Astuti. Higiene dan Sanitasi Pada Pedagang Angkringan Di Kawasan Malioboro Yogyakarta

DOI :

Tabel 3. Hubungan Pengetahuan, Sikap, Fasilitas Sanitasi dengan Higiene Pedagang Angkringan di Kawasan Malioboro

\begin{tabular}{|c|c|c|c|c|c|c|c|c|}
\hline \multirow{2}{*}{ Variabel } & \multicolumn{6}{|c|}{ Higiene Pedagang } & \multirow{2}{*}{ p value } & \multirow{2}{*}{$\begin{array}{c}\text { RP } \\
(\mathrm{CI} 95 \%)\end{array}$} \\
\hline & Buruk & $\%$ & Baik & $\%$ & Total & $\%$ & & \\
\hline \multicolumn{9}{|l|}{ Pengetahuan } \\
\hline Rendah & 7 & 87.5 & 1 & 12.5 & 8 & 100 & \multirow[t]{2}{*}{0.222} & \\
\hline Tinggi & 19 & 59.4 & 13 & 40.6 & 22 & 100 & & \\
\hline \multicolumn{9}{|l|}{ Sikap } \\
\hline Buruk & 3 & 75 & 1 & 25 & 4 & 100 & \multirow[t]{2}{*}{1.000} & \\
\hline Baik & 23 & 63.9 & 13 & 36.1 & 36 & 100 & & \\
\hline \multicolumn{9}{|c|}{ Fasilitas Sanitasi } \\
\hline Buruk & 22 & 75.9 & 7 & 24.1 & 29 & 100 & \multirow[b]{2}{*}{0.029} & 2.086 \\
\hline Baik & 4 & 36.4 & 7 & 63.6 & 11 & 100 & & $(0.930-4.681)$ \\
\hline
\end{tabular}

Tabel 3 dapat dilihat bahwa proporsi higiene pedagang berdasarkan pengetahuan, bahwa yang paling banyak yaitu pedagang yang mempunyai pengetahuan tinggi dengan higiene yang buruk berjumlah 19 responden (59.4\%). Hasil analisis dari uji Fisher diperoleh $p$ value 0.222 ( $p$ value > 0.05) maka dapat diketahui bahwa tidak ada hubungan antara pengetahuan dengan higiene pada pedagang angkringan di kawasan Malioboro. Sedangkan untuk proporsi higiene pedagang berdasarkan sikap, bahwa yang paling banyak yaitu pedagang yang mempunyai sikap baik dengan higiene yang buruk berjumlah 23 responden (63.9\%). Hasil analisis dari uji Fisher diperoleh $p$ value 1.000 ( $p$ value $>0.05$ ) maka dapat diketahui bahwa tidak ada hubungan antara sikap dengan higiene pada pedagang angkringan di kawasan Malioboro. Dan proporsi higiene pedagang berdasarkan fasilitas sanitasi, bahwa yang paling banyak yaitu pedagang yang mempunyai fasilitas sanitasi buruk dengan higiene yang buruk ada 22 responden (75.9\%). Hasil analisis dari uji Fisher diperoleh $p$ value 0.029 ( $p$ value $<0.05)$ maka dapat diketahui bahwa ada hubungan antara fasilitas sanitasi dengan higiene pada pedagang angkringan di kawasan Malioboro. Dan hasil statistik dengan $\alpha=0.05$ didapatkan nilai Rasio Prevalensi $(\mathrm{RP})=2.086$ (dengan CI 95\%=0.930-4.681), yang berarti bahwa pedagang yang memiliki fasilitas sanitasi buruk mepunyai peluang 2.086 kali memiliki higiene yang buruk dibandingkan dengan pedagang yang memiliki fasilitas sanitasi baik.

\section{Pembahasan}

Pengetahuan higiene dan sanitasi pada pedagang angkringan di kawasan Malioboro Hasil penelitian pada pengetahuan pedagang angkringan di kawasan Malioboro ini terdapat 8 pedagang (20\%) yang memiliki pengetahuan tentang higiene sanitasi yang rendah, dan 32 pedagang (80\%) memiliki pengetahuan yang tinggi, artinya terdapat banyak pedagang yang mempunyai pengetahuan tinggi daripada pengetahuan rendah. Pengetahuan pedagang angkringan di kawasan Malioboro pada penelitian ini sudah 
baik karena mereka bisa menjawab dengan benar mengenai beberapa pertanyaan seperti 32 pedagang mengetahui manfaat menjaga kebersihan pada saat berdagang, 33 pedagang mengetahui akibat dari kebiasaan hidup yang tidak bersih, dan 40 pedagang mengetahui dampak yang ditimbulkan jika tidak menjaga kebersihan lingkungan.

Pedagang makanan idealnya memiliki pengetahuan tentang keamanan pangan dan keterampilan dalam praktik sanitasi yang baik dalam pengolahan dan penyajian makanan, sehingga makanan yang disajikan dapat terjamin keamanannya ${ }^{11}$. Pengetahuan dapat dipengaruhi oleh beberapa faktor seperti pendidikan, umur, dan lingkungan kerja ${ }^{12}$.

Penelitian ini sejalan dengan penelitian terdahulu tentang pengetahuan pengolah makanan bahwa responden dengan pengetahuan baik (59.5\%) lebih banyak daripada responden yang berpengetahuan kurang $(40.5 \%)$, pengetahuan baik lebih banyak daripada pengetahuan rendah karena dari banyaknya responden yang memiliki umur $>35$ tahun $^{13}$.

\section{Sikap tentang higiene sanitasi pedagang angkringan di Kawasan Malioboro}

Hasil penelitian pada pedagang angkringan di Kawasan Malioboro ini, pedagang yang memiliki sikap baik berjumlah 36 orang $(90 \%)$ lebih banyak daripada yang memiliki sikap buruk yang berjumlah 4 orang (10\%). Artinya, pedagang banyak yang bersikap baik dalam hal higiene sanitasi. Sikap pada pedagang angkringan di kawasan Malioboro ini sudah baik dengan ditunjukkannya oleh berbagai pernyataan seperti pada 37 pedagang setuju bahwa pedagang harus menyediakan tempat sampah, 39 pedagang setuju mengenai kebersihan tempat berjualan harus dijaga oleh pedagang, 38 pedagang setuju jika mencuci piring harus menggunakan sabun dan air yang mengalir, dan 36 pedagang setuju mengenai pernyataan bahwa setiap makanan yang disajikan harus mempunyai tempat terpisah.

Penelitian terdahulu menyatakan bahwa sikap penjamah yang positif akan mengarah pada tindakan praktik penjamah makanan yang baik pula ${ }^{14}$. Lebih banyaknya sikap yang positif karena dalam penelitian ini banyak pedagang yang sudah pernah mengikuti pelatihan mengenai higiene sanitasi makanan. Hasil pengukuran sikap dapat dipengaruhi oleh pendidikan, pengalaman yang di dapat, budaya yang biasa dilakukan serta fasilitas yang tersedia ${ }^{15}$.

Pembentukan sikap dipengaruhi oleh beberapa faktor yaitu pengalaman pribadi, orang yang dianggap penting, media massa, serta lambang pendidikan dan agama ${ }^{16}$. Pengalaman pribadi pada penelitian ini seperti pada lama berjualan pedagang, pedagang yang berjualan lebih dari 5 tahun ada 36 pedagang (90\%) dan pedagang yang berjualan kurang dari 5 tahun ada 4 pedagang (10\%). Karena seseorang yang telah lama bekerja akan memperoleh banyak pengalaman sehingga sikapnya bisa menjadi baik.

\section{Fasilitas sanitasi pedagang angkringan di kawasan Malioboro}

Hasil penelitian pada pedagang angkringan di kawasan Malioboro ini, jumlah angkringan yang memiliki fasilitas sanitasi 
Dyah Suryani dan Fardhiasih Dwi Astuti. Higiene dan Sanitasi Pada Pedagang Angkringan Di Kawasan Malioboro Yogyakarta

DOI :

buruk berjumlah 29 angkringan (72.5\%), dan angkringan yang memiliki fasilitas sanitasi baik berjumlah 11 angkringan (27.5\%). Artinya, pada angkringan di kawasan Malioboro masih banyak angkringan yang memiliki fasilitas sanitasi buruk. Fasilitas sanitasi yang baik dalam penelitian ini yaitu memiliki tempat yang mudah dibersihkan, adanya air bersih, terdapat tempat makanan dan peralatan yang tertutup, tersedia tempat cuci tangan, tersedia tempat sampah, adanya tempat pembuangan limbah cair dan terdapat lap atau serbet. Namun di tempat penelitian masih banyak yang memiliki fasilitas sanitasi buruk karena hanya terdapat 10 angkringan yang menyimpan makanan dalam keadaan tertutup, 23 angkringan tidak memiliki tempat untuk pembuangan limbah cair, dan 40 angkringan tidak memiliki tempat penyimpanan peralatan makan yang tertutup. dengan tidak adanya penutup pada penyimpanan makanan dan peralatan makanan dapat mengakibatkan makanan menjadi tercemar.

Hasil penelitian ini sejalan dengan penelitian terdahulu bahwa jumlah ketersediaan fasilitas sanitasi di warung pecel tumpang Kota Kerdiri yang memiliki fasilitas sanitasi buruk yaitu 10 warung dan yang mempunyai fasilitas sanitasi baik yaitu 7 warung. Jumlah pedagang yang memiliki fasilitas sanitasi buruk lebih banyak karena pedagang tidak mempunyai fasilitas cuci tangan dengan air yang mengalir. Tempat cuci tangan yang dimiliki pedagang hanya berupa air yang ditampung di ember dan tidak tertutup ${ }^{17}$.

Kondisi angkringan yang masih banyak mempunyai fasilitas sanitasi yang buruk harus diperhatikan secara serius, karena dapat memberikan dampak bagi mereka yang mengkonsumsi makanan yang kurang steril dalam penyajiannya. Terlebih lagi makanan yang ada di angkringan merupakan makanan yang biasa dikonsumsi oleh banyak kalangan, dimana masih ada beberapa orang yang belum terlalu memahami dengan baik akan bahaya yang dapat timbul jika mengkonsumsi makanan yang tidak bersih. Buruknya fasilitas sanitasi juga bisa disebabkan karena pedagang selama berjualan hanya ingin mendapatkan keuntungan tanpa memikirkan fasilitas yang ada dalam angkringan mereka.

\section{Higiene pedagang angkringan di kawasan Malioboro \\ Berdasarkan hasil penelitian pada} pedagang angkringan di kawasan Malioboro ini, jumlah pedagang yang mempunyai higiene yang buruk yaitu 26 pedagang (65\%), dan pedagang yang mempunyai higiene yang baik berjumlah 14 pedagang (35\%). Artinya, masih banyak pedagang yang mempunyai praktik higiene yang buruk. Pedagang angkringan di kawasan Malioboro ini masih banyak yang memiliki kategori buruk, seperti hanya ada 2 pedagang yang menggunakan celemek, pedagang yang menutup kepala hanya terdapat 24 orang, hanya terdapat 17 pedagang yang mencuci tangan sebelum melakukan kegiatan, dan sebagainya.

Seorang penjamah makanan apabila tidak memperhatikan kebersihan dirinya mulai dari mencuci tangan, rambut, badan, kuku, perawatan luka akan memudahkan masuknya bakteri ke dalam makanan sehingga makanan yang diolah dapat terkontaminasi. Begitu 
halnya dengan pakaian kerja serta kebersihan pakaian kerja atau celemek, penjamah makanan sebaiknya menggunakan pakaian kerja atau celemek. Kebersihan pakaian kerja atau celemek itu perlu diperhatikan, karena bila penjamah pada saat pengolahan tidak menggunakan pakaian kerja atau celemek maka sisa-sisa kotoran pengolahan akan menempel pada pakaian, sehingga mengakibatkan pakaian menjadi kotor dan tidak higiene serta dapat menyebabkan kotoran tersebut berpindah ke makanan yang diolah ${ }^{18}$.

Penelitian ini sejalan dengan penelitian terdahulu bahwa jumlah pedagang yang mempunyai praktik higiene sanitasi makanan yang buruk yaitu 42 pedagang $(87.5 \%)$ lebih banyak daripada pedagang yang mempunyai praktik higiene sanitasi makanan yang baik yaitu 6 pedagang $(12.5 \%)$. Banyak pedagang yang memiliki praktik higiene sanitasi buruk karena masih ditemukan pedagang yang tidak mencuci tangan dengan sabun, berbicara saat sedang mengolah makanan dan menyentuh makanan langsung dengan tangan ${ }^{14}$.

Hubungan pengetahuan dengan higiene pedagang angkringan di kawasan Malioboro Berdasarkan hasil uji analisis bivariat menggunakan uji Fisher diperoleh $p$ value 0,222 ( $p$ value > 0,05) maka dapat diketahui bahwa tidak ada hubungan antara pengetahuan dengan higiene sanitasi pada pedagang angkringan di kawasan Malioboro. Hasil pada penelitian ini sejalan dengan penelitian terdahulu bahwa tidak ada hubungan antara pengetahuan dengan praktik higiene sanitasi penjamah makanan di sepanjang Jalan Raya Tajem Maguwoharjo Yogyakarta, dengan masih terdapatnya pedagang yang mempunyai pengetahuan baik tetapi memiliki praktik higiene sanitasi yang kurang dikarenakan banyaknya responden yang memiliki pengalaman kerja kurang dari 5 tahun $(73.8 \%)$ sehingga pengalaman kerja tersebut dapat mempengaruhi praktik higiene sanitasi yang dimiliki oleh penjamah makanan ${ }^{19}$.

Hasil penelitian ini menghasilkan bahwa tidak ada hubungan antara pengetahuan dengan higiene pedagang dikarenakan pedagang angkringan di kawasan Malioboro rata-rata memiliki pengetahuan yang tinggi, pedagang sebenarnya mengetahui mengenai higiene sanitasi namun dikarenakan tempat dalam berjualan ini terbatas dan keterbatasannya fasilitas maka pedagang memiliki perilaku higiene yang buruk. Jumlah pedagang yang mempunyai pengetahuan tinggi dengan higiene yang buruk ada 19 orang (59.4\%). Hasil tersebut dapat dibuktikan dengan terdapat 31 pedagang dalam penelitian ini dapat menjawab benar mengenai penyebab menurunnya kualitas makanan yaitu dengan cara makanan dibiarkan dalam kondisi terbuka, meskipun pedagang mengetahui bahwa membiarkan makanan yang terbuka merupakan penyebab menurunnya kualitas makanan, namun pedagang dalam hal praktiknya masih ada yang membiarkan makanan itu terbuka tanpa diberi penutup.

Pengetahuan pedagang tidak berpengaruh secara langsung dengan higiene pedagang, selain pengetahuan masih terdapat faktor lain yang dapat mempengaruhi higiene pedagang seperti pengalaman kerja ${ }^{19}$. Pengetahuan seseorang dapat diperoleh secara internal maupun eksternal. Pengetahuan secara 
Dyah Suryani dan Fardhiasih Dwi Astuti. Higiene dan Sanitasi Pada Pedagang Angkringan Di Kawasan Malioboro Yogyakarta

DOI :

internal yaitu pengetahuan yang berasal dari dirinya sendiri berdasarkan pengalaman hidup. Sedangkan pengetahuan secara eksternal yaitu pengetahuan yang diperoleh dari orang lain yang dianggap penting bagi dirinya ${ }^{20}$. Pengetahuan yang diperoleh secara internal maupun eksternal akan menambah pengetahuan pedagang makanan tentang higiene sanitasi ${ }^{21}$.

Berdasarkan hasil yang diperoleh bahwa ternyata pengetahuan tidak berhubungan dengan higiene karena masih banyak pedagang yang mempunyai pengetahuan tinggi namun dalam hal praktik higiene nya masih buruk, hal tersebut bisa saja terjadi karena tingginya pengetahuan pedagang dapat diperoleh dari mana saja seperti pengalaman sehari-hari maupun dari berbagai media massa atau komunikasi. Walaupun sebenarnya pedagang tahu akan pentingnya higiene sanitasi, namun karena keterbatasan tempat berjualan yang hanya seperti itu makanya pedagang masih susah dalam melakukan praktik higiene yang baik.

Hubungan sikap dengan higiene pada pedagang angkringan di kawasan Malioboro Berdasarkan hasil uji analisis bivariat menggunakan uji Fisher diperoleh $p$ value 1.000 ( $p$ value > 0.05) maka dapat diketahui bahwa tidak ada hubungan antara sikap dengan higiene pada pedagang angkringan di kawasan Malioboro. Hasil pada penelitian ini sejalan dengan penelitian terdahulu bahwa tidak ada hubungan antara sikap dengan praktik higiene makanan di wisata Pantai Glagah Kabupaten Kulon Progo, dengan masih banyaknya pedagang yang belum pernah mengikuti pelatihan mengenai higiene sanitasi makanan ${ }^{14}$.
Sikap tidak berhubungan dengan higiene pada pedagang angkringan di kawasan Malioboro ini karena fasilitas yang mereka miliki untuk berdagang ini tidak lengkap, jadi walaupun rata-rata jumlah pedagang yang memiliki sikap baik itu lebih banyak namun karena fasilitas kurang sehingga mereka dalam melaksanakan praktik higiene masih buruk. Jumlah pedagang yang memiliki sikap baik dengan higiene sanitasi yang buruk yaitu 23 pedagang (63.9\%). Hal ini bisa dibuktikan pada pedagang yang bersikap baik dengan menjawab setuju pada pertanyaan pedagang mencuci piring dengan sabun dan air mengalir sebanyak 38 pedagang, namun pada kenyataannya mereka mencuci piring menggunakan air yang berada dalam ember, bukan dengan air yang mengalir. Hal tersebut terjadi karena fasilitas yang mereka miliki tidak lengkap, mereka tidak mempunyai kran sendiri dan hanya menampung air dengan ember yang digunakan untuk mencuci.

Pengetahuan tidak berhubungan dengan higiene pedagang, maka sikap juga menjadi tidak berhubungan dengan higiene pedagang. Selain itu, karena kebiasaan pedagang menganggap hal yang mereka lakukan itu sudah menjadi kebiasaan mereka dan belum pernah terjadi apa-apa maka pedagang-pedagang tersebut tidak memperbaiki perilaku higiene mereka menjadi yang lebih baik.

\section{Hubungan fasilitas sanitasi dengan higiene sanitasi pedagang angkringan di kawasan Malioboro \\ Berdasarkan hasil uji analisis bivariat menggunakan uji Fisher diperoleh $p$ value $0,029$ ( $p$ value $<0,05)$ maka dapat diketahui}


bahwa ada hubungan antara fasilitas sanitasi dengan higiene sanitasi pada pedagang angkringan di kawasan Malioboro. Dan hasil statistik dengan $\alpha=0,05$ didapatkan nilai Rasio Prevalensi $(\mathrm{RP})=2,086$ (dengan CI 95\%= 0,930-4,681), yang berarti bahwa pedagang yang memiliki fasilitas sanitasi buruk mempunyai peluang 2,086 kali memiliki higiene yang buruk dibandingkan dengan pedagang yang memiliki fasilitas sanitasi baik.

Hasil pada penelitian ini sejalan dengan penelitian terdahulu bahwa terdapat hubungan antara ketersediaan fasilitas dengan praktik sanitasi makanan di sekitar wisata Pantai Logending Kecamatan Ayah Kabupaten Kebumen, penelitian ini dapat berhubungan karena masih banyak pedagang yang belum pernah melaksanakan pelatihan higiene sanitasi makanan. Dengan adanya pelatihan, maka dapat melatih pedagang agar pedagang dapat berupaya menyediakan fasilitas sanitasi yang baik $^{22}$.

Dalam penelitian pada pedagang angkringan di kawasan Malioboro ini terdapat 22 angkringan yang memiliki fasilitas sanitasi buruk dengan higiene sanitasi buruk. Hal ini dapat dilihat dari adanya 30 angkringan yang menyajikan makanan tanpa penutup. Hal ini dapat dilihat dari adanya 30 angkringan yang menyajikan makanan tanpa penutup. Penelitian terdahulu menyatakan bahwa praktik kebersihan lingkungan yang buruk dari pedagang makanan kaki lima harus dihilangkan, dan itu merupakan tugas yang tidak mudah. Pengawasan keamanan makanan yang rutin dari pihak pemerintah dan praktik keamanan pangan yang baik, kondisi serta fasilitas lingkungan seharusnya ditingkatkan oleh pedagang kaki lima ${ }^{23}$. Juga masih terdapat angkringan yang tidak memiliki tempat untuk pembuangan limbah cair, dengan tidak adanya tempat yang digunakan untuk pembuangan limbah tersebut maka para pedagang hanya membuang limbah cair secara sembarangan di depan maupun di samping tempat berjualan mereka. Dari fasilitas sanitasi yang masih buruk dapat menyebabkan terjadinya tempat perkembangbiakan vektor penyakit yang dapat menularkan penyakit melalui makanan ${ }^{24}$. Penelitian terdahulu juga menyatakan bahwa penjual makanan streetfood di India banyak yang membuang sampah di lokasi jualannya karena tidak menyediakan tempat sampah yang tertutup, hal ini akan mendatangkan vektor seperti lalat dan tikus sehingga menyebabkan kontaminasi makanan ${ }^{25}$.

Pedagang yang memiliki fasilitas sanitasi yang buruk, bisa disebabkan karena mereka hanya berjualan di trotoar dimana tempat berjualan sangat terbatas sehingga tidak dapat melengkapi fasilitas sanitasi seperti di tempattempat yang bagus. Selain itu disebabkan karena kurangnya informasi yang didapatkan, kurangnya informasi inilah yang menyebabkan pedagang memiliki fasilitas sanitasi yang kurang. Hal ini sesuai dengan teori yang menyatakan bahwa media informasi merupakan salah satu media yang membantu meningkatkan pendidikan kesehatan, yang akan membantu menegakkan pengetahuan yang diperoleh sehingga pengetahuan tersebut akan lebih tersimpan di dalam ingatan ${ }^{12}$. Latar belakang sosial ekonomi dan budaya tertentu memiliki pengaruh yang signifikan terhadap perilaku 
Dyah Suryani dan Fardhiasih Dwi Astuti. Higiene dan Sanitasi Pada Pedagang Angkringan Di Kawasan Malioboro Yogyakarta

DOI :

pedagang kaki lima dan praktik higienisnya.

Jenis kelamin pedagang (pria atau wanita), tingkat pendidikan, pendapatan, usia adalah faktor penting yang mempengaruhi reaksi pedagang terhadap keamanan pangan. Pedagang kaki lima dengan pendidikan yang memadai dan status ekonomi yang baik akan mempraktekkan langkah-langkah yang lebih baik untuk meningkatkan kebersihan makanan yang mereka sajikan ${ }^{26}$.

\section{Kesimpulan dan Saran}

\section{Kesimpulan}

Berdasarkan hasil dan pembahasan diatas dapat disimpulkan bahwa tidak ada hubungan antara pengetahuan dan sikap dengan higiene pedagang. Dan terdapat hubungan antara fasilitas sanitasi dengan higiene pedagang.

\section{Saran}

Perlu ditingkatkan mengenai inspeksi kepada para pedagang angkringan dan upaya promosi mengenai pentingnya higiene sanitasi bagi para pedagang angkringan.

Keterbatasan dalam penelitian ini adalah penelitian ini menggunakan jenis kuantitatif dengan rancangan cross sectional, yang artinya penelitian ini hanya dilakukan satu kali sehingga peneliti tidak mengamati secara langsung dengan aktivitas sehari-harinya. Data praktik higiene pedagang dalam penelitian ini hanya dilihat menggunakan lembar observasi, dimana dalam penelitian ini hanya diukur sebanyak satu kali sehingga peneliti tidak mengamati secara berkelanjutan untuk mengetahui kebiasaan pedagang angkringan dalam menerapkan praktik higiene.

\section{Daftar Pustaka}

1. Depkes RI. Modul Kursus Higiene Dan Sanitasi Makanan dan Minuman. Jakarta: Dirjen PPM dan PL. 2010.

2. Yulia dan Prayitno. Efektifitas Konsentrasi Asap Cair Dari Tempurung Kelapa Terhadap Angka Kuman. Jurnal Vokasi Kesehatan; 2016. Vol.2, Hal. 385-389.

3. WHO. WHO's First Ever Global Estimates of Foodborne Diseases Find Children Under 5 Account for Almost One Third of Deaths.

http://www.who.int/mediacentre/news/rele ases/2015/foodborne-diseaseestimates/en/. 2015. Diakses pada 13 April 2018.

4. Cahyaningsih, C.T., Kushadiwijaya, H., dan Tholib, A. Hubungan Higiene Sanitasi dan Perilaku Penjamah Makanan dengan Kualitas Bakteriologis Peralatan Makanan di Warung Makan. Berita Kedokteran Masyarakat, 2009. 25 (4), Hal. 180-188.

5. Suherman, P.A., Ane, L.R., dan Ibrahim. Praktik Hygiene Penjamah dan Sanitasi Peralatan Makanan Jajanan Anak Sekolah Dasar Pada SD di Kel. Antang Kec. Manggala Kota Makassar. Jurnal MKMI 2013. Juni Hal 103-108.

6. Rejeki, S. Sanitasi Hygiene Dan K3. Bandung: Rekayasa Sains. 2015.Hal. 7390

7. Hariyadi dan Ratih. Memproduksi Pangan yang Aman. Jakarta: Dian Rakyat. 2009.

8. BPOM. Berita Keracunan Bulan JanuariMaret Tahun 2016. http//ik.pom.go.id/2014/berita-keracunanbulan-januari-maret-2016. Di akses tanggal 12 April 2018.

9. Dinas Kesehatan Provinsi Yogyakarta. Profil Kesehatan Provinsi Yogyakarta Tahun 2014. Dinas Kesehatan Provinsi Yogyakarta. Yogyakarta; 2015

10. Tengker, V. Ngelencer ke Yogyakarta. Jakarta: PT Gramedia Pustaka Utama. 2017. Hal.183.

11. Sukmawati., Asbar, R., Rochimiwati, S.N., dan Nurwahidah. Tingkat Pengetahuan dan Praktik Penjamah Makanan Tentang Keamanan Pangan Pada Usaha Katering di Kota Makassar. Jurnal Media Gizi Pangan. 2015.Vol. XX, Edisi. 2. Hal. 1-4. 
12. Notoatmodjo, S. Promosi Kesehatan dan Perilaku Kesehatan. Edisi Revisi Jakarta: Rineka Cipta. 2014. Hal. 147-150.

13. Mulyani, R. 2014. Pengetahuan, Sikap dan Perilaku Higiene Pengolah Makanan. Jurnal Keperawatan. Vol.X, No.1. Hal 612.

14. Abdul-Mutalib, N. A., Abdul-Rashid, M. F., Mustaf, S., Amin-Nordin, S., Hamat, R. A., Osman, M. Knowledge, attitude and practices regarding food hygiene and sanitation of food handlers in Kuala Pilah, Malaysia. Food Control, 2012. 27, 289293.

15. Meikawati, W., Astuti, R., Susilawati. Hubungan Pengetahuan dan Sikap Petugas Penjamah Makanan dengan Praktek Higiene dan Sanitasi Makanan di Unit Gizi RSJD Dr. Amino Gondohutomo Semarang. Jurnal Kesehatan Masyarakat Indonesia. 2010.Vol. 6, No.1, Hal. 50-68.

16. Azwar, S. Metode Penelitian. Yogyakarta: Pustaka Belajar Offset; 2005.

17. Putri, G.G., Dewi, Y. Praktik Higiene Perorangan dan Sanitasi Warung Pecel Tumpang di Kota Kediri. Jurnal IKESMA. 2017. Vol. 13, No.2. Hal. 155-162.

18. Hasanah, V.A., Sikap Konsumen Terhadap Kondisi Higiene Sanitasi Penjualan Makanan Pedagang Kaki Lima Trisula Taman Bungkul Surabaya. Jurnal Boga. 2013.Vol.2, No.1, Hal. 126-138.

19. Rahmuniyati, M.E., Maghafirah, M., Sukismanto. Hubungan Pengetahuan dan Sikap Dengan Praktik Higiene Sanitasi Penjamah Makanan di Sepanjang Jalan Raya Tajem Maguwoharjo. Jurnal Forum Ilmiah Kesehatan Mayarakat Respati. 2018.Vol. 3, No.1, Hal. 15-22.

20. Sunaryo. Psikologi Keperawatan. Jakarta: EGC. 2004

21. Djarismawati., Sukana, B., Sugiharti. Pengetahuan dan Perilaku Penjamah tentang Sanitasi Pengolahan Makanan pada Instalasi Gizi Rumah Sakit di Jakarta. Media Penelitian dan Pengembangan. 2004.Vol. 14, No. 03. Hal. 31-37.

22. Wati, C. Faktor yang Berhubungan dengan Praktik Sanitasi pada Pedagang Makanan di Sekitar Wisata Pantai Logending Kecamatan Ayah Kabupaten Kebumen, Unnes Journal of Public Health, 2013. Vol. 2, No. 4, Hal. 1-10.

23. Liu, Z., Zhang, G., Zhang, X. Urban street food in Shijiazhuang city, China: Current status, safety practices and risk mitigating strategies. Food Control;2014. Vol 41, 212-218.

24. Ningsih, R. Penyuluhan Higiene Sanitasi Makanan dan Minuman Serta Kualitas Makanan yang Dijajakan Pedagang di Lingkungan SDN kota Samarinda. Jurnal Kesehatan Masyarakat. 2014.Vol. 10, No.1. Hal. 64-72.

25. Singh, M.C.A.K., Dudeja, L.C.P., Kaushal, M.N., Mukherji, A.C.P., Impact of health education intervention on food safety and hygiene of street vendors: A pilot study. Medical Journal Armed Forced India ; 2016.No. 72. Halaman 265-269.

26. Trafialek, J., Drosinos, E. H., Kolanowski, W., Jakubowska-Gawlik, K.,Tzamalis P.Leksawasdi, N.,Surawang, S.,Kolanowski, W. (2017). Street food vendors' hygienic practices in some Asian and EU countries - A survey. Food Control; 2018. Vol 85, 350-359 